Article

\title{
Sustainable and Balanced Energy Efficiency and Preservation in Our Built Heritage
}

\section{Heidi Norrström}

Department of Architecture, Chalmers University of Technology, Sven Hultins gata 6, Göteborg, SE 412 96, Sweden; E-Mail: heidi.norrstrom@chalmers.se; Tel.: +46-736-403-114;

Fax: $+46-317-722-485$.

Received: 1 April 2013; in revised form: 21 April 2013 / Accepted: 8 June 2013 /

Published: 17 June 2013

\begin{abstract}
Today, conservation work in our built cultural heritage has to be reformulated due to the new energy efficiency requirements put forward. On both a national and an international level, energy efficiency measures are considered key actions within sustainability work, answering to the global issue of climate change. What does this imply for our built heritage? Contemporary conservation is characterized by the concept of sustainability, and integrated conservation is also expected to be sustainable. It is inherent in this tradition, but how are we going to balance the historic and architectural values with the new energy requirements? A research project, Energy Efficiency in Our Cultural Heritage (EEPOCH), consisting of a multiple case study, has been carried out over three years, studying selected objects restored within the Halland Model, a project over a decade long. In EEPOCH the multiple units of analysis are energy efficiency, historic and architectural values, management, and legislation. All are applied to the selected objects. The results and conclusions drawn from the analysis show that there are actions that are possible to take and to recommend, including national inventories of historic values in the existing building stock as well as guidance for the management of historic values on a municipal level for continued sustainable development.
\end{abstract}

Keywords: multiple case study; built heritage; conservation; energy efficiency; multidisciplinarity 


\section{Introduction}

\subsection{Built Heritage}

This research is not about the high profile "Outstanding Universal Value" identified in the World Heritage Convention [1], although one of the built environments restored within the Halland Model, the Varberg Radio Station at Grimeton, is a World Heritage site. Instead it is about our common, everyday, built environment, our inherited cultural spaces; a symbolic expression for human life. "The city ... consists of ... relationships between measurements of its space and the events of its past" as Calvino poetically formulated [2]. Preserving the different time layers generates diversity and also means preserving memory, the intangible value giving meaning to a place for people using it. This heritage must be recognized. Furthermore, the boundaries of the criteria for which kind of buildings are worth preserving are expanding on a local and regional level. In Sweden in the early 1990s, when national funding was available for inventories, about 3,000 buildings were identified as historically valuable in the county of Halland. The new inventory finished in 2010 [3], points out 11,000 buildings in the residential and tertiary sector, and the industrial sector. Similar results are likely to appear in other parts of Sweden and Europe if, and when, inventories are carried out.

\subsection{The Risks}

Built heritage faces two risks today emanating from one source - climate change and our efforts to cope with and mitigate its effects. For the Northern countries the rise of sea levels or droughts are not as big a threat as they are for the Southern countries, or LDCs (Less Developed Countries). The issue is less about constructing resilience for coping with changing climate, than about cutting net emissions of greenhouse gases. This is manifest in the European Directive 2009/28/EC [4] with the objective of $20 \%$ renewable energy sources by the year 2020, Directive 2012/27/EU [5] for energy end-use efficiency and energy service, and Directive 2010/31/EC [6] on the energy performance of buildings. Parts of the content in the directives have been implemented in Sweden in the mandatory provisions for building and constructions, BBR, BFS 2011:6 [7] which states requirements for both energy efficiency and caution within historic buildings when they are altered or extended. BBR equates existing buildings with new constructions in its requirements for energy efficiency. Then there is the law, SFS 2006:985 [8], and the regulation, SFS 2006:1592 [9], on energy declarations where cost efficient energy measures should be suggested to the real estate owner.

The two risks our built heritage faces due to the legislation are: exhaustive refurbishments with the energy measures undertaken leading to the destruction of cultural, historic, and architectural value, and the risk that overly cautious management might completely exclude energy efficiency measures. Long-term sustainable management of cultural values in our built heritage presupposes change triggered by the need for low running costs and sufficient space for the functions required of the building. There must be an economy for the maintenance of existing values and new functions for the buildings otherwise there is no incentive for the owners to preserve. One aim of this research is to explore how balanced energy measures and preservation can result in both low energy use with low running costs and better indoor climate, and thus contribute to decreasing $\mathrm{CO}_{2}$ emissions. 


\subsection{The Halland Model}

The objects and teams investigated in this multiple case study, are buildings restored within the Halland Model and their teams, leadership, and organization. The Halland Model was a project that lasted over a decade, started in the 1990's recession, where about 100 objects at risk were restored and over 1,100 construction workers and apprentices were trained in traditional building techniques under the supervision of skilled craftsmen and conservation officers. After the completion of each conservation work, the improved premises made new functions available. They were seen as resources important to regional identity, for both use and development [10].

Both preservation and energy efficiency were taken into account in the conservation work. The Halland Model provides examples of the management of energy performance without diminishing cultural value and social history. Thus the Halland Model is appropriate for further research. It is the built environment from the epoch of traditional craftsmanship and constructed before 1945 that is studied in this research project.

The Halland Model was developed into a regional cross-sector joint-action network, aiming at sustainable growth including strengthening competitiveness, use of renewables, recycling of materials, and development of building conservation. About 1,500 contractors and suppliers have been involved, and about 400 new jobs have been created directly as a result of the execution of the Halland Model [10]. The concept of the Halland Model has been exported e.g., to the Baltic Sea Region, Russia, Poland, and Iceland in regional projects for sustainable development. The experience has been widely disseminated because of its proven usability. It is within this concept that the teams and leadership are studied in this research project.

\subsection{The Aim of the Research}

There are two overall research objectives. The first is to design a theoretical model that is sustainable and application-oriented for an integrated balancing of energy and preservation requirements without diminishing the tangible and intangible values in our built heritage. The second is to explore and design a theoretical model for cooperation between the professions involved and a good working climate in the preservation process.

In the initial stages of this research, a comprehensive information search through university databases was conducted on this new combined field. The aim was to find out if others had tried to create theories or models of the kind that this research is aiming at. The search showed that the combination of built heritage, conservation, and energy efficiency had not been explored to any great extent and still was not established. There were examples of case studies, but not an in-depth study of this new combined field and hence no conclusions about how to obtain a balanced assessment of both energy issues and conservation issues. There were no established theories to use or to verify. In light of this, the aim of the research is theory building for the development of applied methods.

\subsection{The Architectural Stance}

Architecture appears predominantly as an applied science for practicing architects. Hence pragmatism and critical realism are common philosophical stances. This also corresponds well with the 
design process, which is inductive. Architecture is not only descriptive, but also prescriptive, and must always consider human wellbeing and the different functions of the building. A stimulating built environment is varied, and preserving the different time layers ensures diversity. Furthermore, taking care of what we have already manufactured and invested in, is important from a resource and techno-economic perspective. About $90 \%$ of the existing buildings will still be here in 50 years, and the potential for energy efficiency in the existing building stock is demonstrable. Sustainable architecture cannot be called sustainable if it is not also energy efficient, but this is only one of many subject matters that architects should have knowledge of and control over. The case study methodology is therefore a good choice as it permits mixing methods appropriate for each subject investigated.

\section{Results and Discussion}

The three buildings chosen were Fattighuset, Teatern, and Tyreshill. The results of the energy calculations and assessment of historic and architectural values are presented below as short summaries. The results on management and teamwork, and on laws and regulations, are presented under separate headings. Table 1 below shows an overview of two units of analysis.

Table 1. The energy uses are measured, the $\mathrm{CO}_{2}$ emissions are calculated with the Swedish Environmental Protection Agency’s (Naturvårdsverkets) emission factors [11].

\begin{tabular}{cccc}
\hline Object & Energy use & $\mathbf{C O}_{2}$ emissions & Cultural and historic values \\
\hline Fattighuset & $216 \mathrm{MWh} /$ year & 16.74 tons/year & Best preserved \\
Teatern & $108 \mathrm{MWh} /$ year & 20.53 tons/year & Well preserved \\
Tyreshill & $37 \mathrm{MWh} /$ year & - & Moderately preserved \\
\hline
\end{tabular}

\subsection{Fattighuset}

Fattighuset, Drottning Kristina 2, Halmstad is the best preserved building, but has the highest energy use. It was built in stages; in 1859 and 1879, and the back wing in 1891 and in 1901. Drawings for this were made by Hans Strömberg and Sven Gratz, two architects from Göteborg.

The key results are:

(1) The tenants experience poor comfort levels. It is cold during winter in areas around windows and doors. The attic floor is overheated during summer. There is a problem with fungus growth in the foundation. A dehumidifier was installed in 2001.

(2) The results from the conservation work are considered to be very good with well-preserved authenticity and patina. In short, preservation issues in Fattighuset have been given foremost priority at the expense of indoor comfort and energy issues.

Fattighuset has mainly been used by the fire brigade. Both buildings have a solid red $11 / 2$-stone brick construction, and partitions and floors are wooden. The buildings are made of local materials, worked by skilled craftsmen. They have well preserved original forms, expressive exteriors, and preserved interior furnishing. Most of the old doors, windows, stairs, floor, and roof cornices etc. have preserved old features. The almost intact floor plans have a general character, which enables different activities to take place within them, and as such possesses high architectural quality. The buildings, and 
especially the back wing, have great authenticity and patina. Fattighuset has classification 1 in the city's preservation plan: a building of great cultural and historic value with an exterior that cannot be altered.

The new mechanical continuous exhaust ventilation is placed in a separate room in the attic and the ducts are visible in the corridors. Fresh air is supplied through vents in the brick wall. The tenants experience poor comfort levels. It is cold during winter, especially in areas near the fresh air vents and around windows and doors. On the interior walls, by the fresh air vents, the temperature was measured as $9{ }^{\circ} \mathrm{C}$, and simultaneously the temperature outdoors was measured as $0{ }^{\circ} \mathrm{C}$. In the oldest part of the building, on the ground floor, there is a boiler room where the exchanger for district heating is situated. There is also a problem with the foundation. Fungus growth in the stone foundation occurred in the beginning of 2001 and was then excavated, and a dehumidifier with continuous measuring and control was installed. When the conservation was carried out the earlier roof garrets were replaced with roof windows, and $175 \mathrm{~mm}$ of insulation was added to the interior side of the roof. During the summer, the offices on the attic floor are overheated despite this. The conservation work was carried out in 1996. After its completion, Fattighuset was let out to shopkeepers and offices.

The measured energy consumption for heat and electricity is $216 \mathrm{MWh} /$ year. Total area $\mathrm{A}_{\text {temp }}$ amounts to $1,062 \mathrm{~m}^{2}$. The definition for $A_{\text {temp }}$ is the area heated to $10{ }^{\circ} \mathrm{C}$ or more. The key figure for energy consumption is $204 \mathrm{kWh} / \mathrm{m}^{2}$ and per year. This is considered high for an old building in this category, type code 826 , according to the comparative key figure given, statistic interval $144-200 \mathrm{kWh} / \mathrm{m}^{2}$ and per year, when calculating the energy performance of the building at Boverket's web site [12]. Fattighuset is heated by district heating and the $\mathrm{CO}_{2}$ emissions calculated are 16.74 tons/year.

Figure 1 below shows the expressive brick façade of Fattighuset and the hose tower, once used for drying the fire brigade's hoses after use. The results from the conservation work are considered good, with well-preserved authenticity and patina, but, in short, preservation issues in Fattighuset have been given foremost priority, at the expense of the indoor comfort and energy issues.

Figure 1. Fattighuset's North façade, facing Lilla Torg in Halmstad. Photo Eva Gustafsson, Heritage Halland at the Regional Museum Halland.

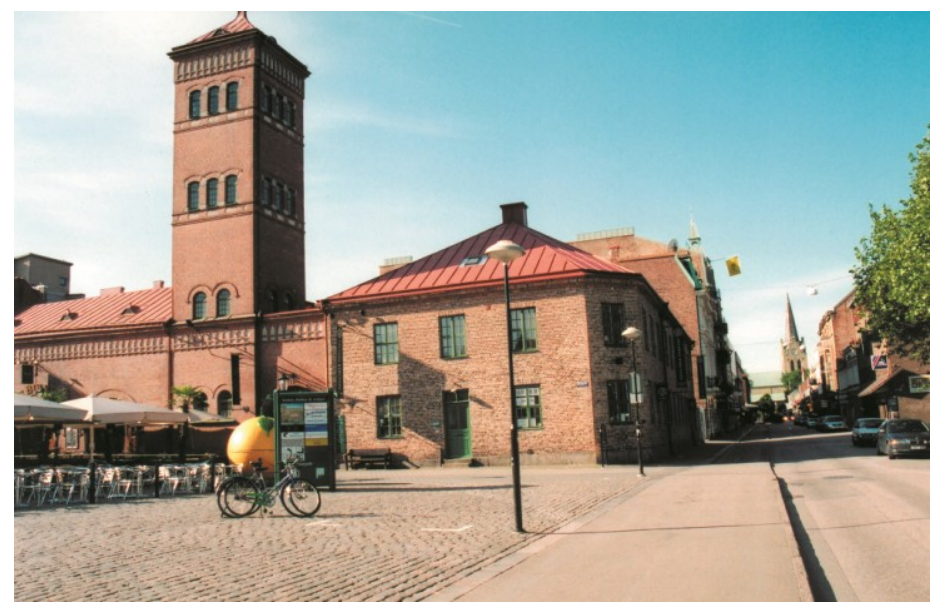

\subsection{Teatern}

Teatern, Laxen 5-8, Laholm, is a well-preserved building with a reasonable energy use. It was built in 1913 with drawings by Per Lennart Håkansson, and was refurbished in the 1950s. 
The key results are:

(1) In Teatern the original foyer, auditorium, and restroom were restored to their former grandeur. The ceiling was uncovered. All plastic paint was removed from the walls, and the damaged parts were restored with traditional paint.

(2) The authenticity in the building's appearance is high although it lacks some of the patina of 1913 mostly due to the 1950s refurbishment. The energy efficiency measures have been nicely adapted to the building and are not experienced as disturbing the interior spaces.

Teatern is the local theatre and has a solid $21 / 2$-stone brick construction with a plastered façade. Partitions and floors are wooden, except for the auditorium's added inner roof construction of steel. In Teatern the original interior of the foyer, the auditorium, and the official restroom, for refreshments and use between acts were restored to their former state with lime plaster and gold. The plastered façade was altered in the 1950s, but was not restored during the conservation work in 1995. Still, Teatern is one of the most dominant buildings at Hästtorget in the old town, Gamleby, and has classification 1 in the city's preservation plan: a building of great cultural and historic value.

Teatern was restored in 1995 within the Halland Model. During the conservation work, $300 \mathrm{~mm}$ insulation was added to the inner vaulted steel roof over the auditorium, and ventilation with both exhaust/supply air and a heat exchanger for heat recovery was installed. The vaulted windows in the auditorium were reproduced and partly mounted with three window-panes. These were the main energy efficiency actions carried out in Teatern. The measured energy consumption for heat and

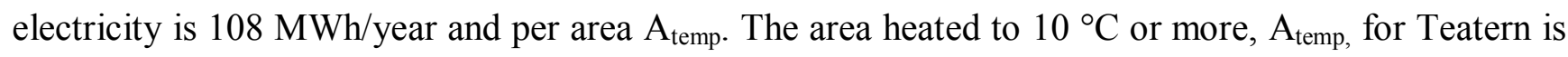
$884 \mathrm{~m}^{2}$. The key figure for energy consumption is $122 \mathrm{kWh} / \mathrm{m}^{2}$ and per year. This is considered low for an old building in this category, type code 826 , according to the comparative key figure given, statistic interval $123-185 \mathrm{kWh} / \mathrm{m}^{2}$ and per year, when calculating the energy performance of the building at Boverket's web site [12]. Teatern is heated by a gas boiler and the calculated $\mathrm{CO}_{2}$ emissions are 20.53 tons/year.

The authenticity in the building's appearance is high although it lacks some of the patina of 1913, mostly due to the 1950s refurbishment as seen in the building's façade in Figure 2 below. The energy efficiency measures have been nicely adapted to the building and are not experienced as disturbing.

Figure 2. The South façade of Teatern, facing Hästtorget in Laholm. Photo Eva Gustafsson, Heritage Halland at the Regional Museum Halland.

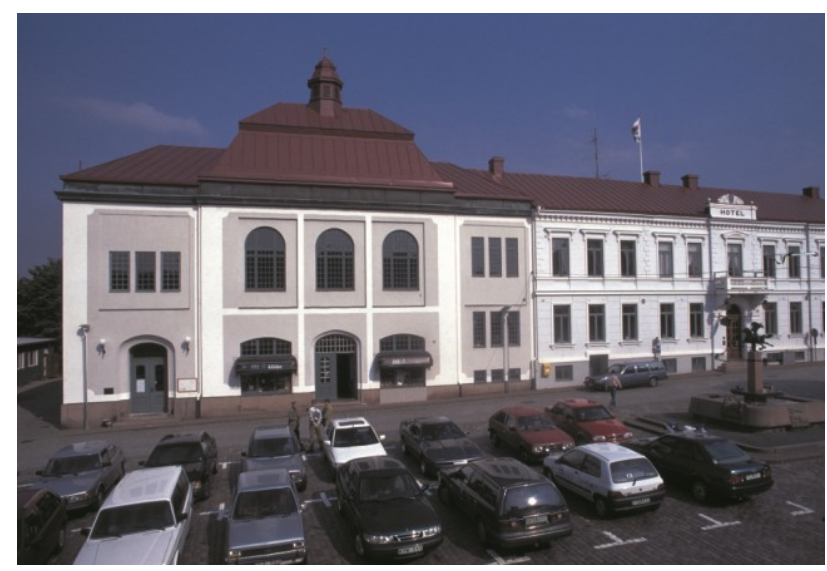




\subsection{Tyreshill}

Tyreshill, Rydö 3:20, Rydöbruk, Hylte, is the least preserved building, with energy use a little too high, considering the energy measures carried out. It was constructed in 1907, and was both designed and built by a local builder.

The key results are:

(1) The completion of the restoration shows a very comfortable house, warm, with no draughts. It has all the facilities needed for a household of today. The appearance and façades are original but there is no patina in the interior.

(2) The cultural value is considered moderate, but Tyreshill has high value in its context as a part of the young community's history. Usability, comfort, and energy issues were prioritized at the expense of the original authenticity and patina, due to its poor original condition.

Tyreshill has a solid timber construction and was planned as a private house for three families, but was remodelled in 1949 for five families. According to the local preservation plan, it is the oldest house in the industrial community Rydö Bruk. Tyreshill has a typical red wooden panel façade with white corners, and it was quite dilapidated in the 1990s. The owner at that time wanted it to be demolished, but the building committee did not allow it. It was renovated in 1997-1998 and most of the exterior façade is intact, despite the otherwise poor condition. The interior was totally refurbished and even parts of the construction on the ground floor had to be reproduced. The construction details of the interior woodwork had to be produced by working from old models. The attic was insulated with $200 \mathrm{~mm}$ mineral wool during the restoration, and $45 \mathrm{~mm}$ was added to the interior side of the walls. Low emission glass was selected for the inner panes of the windows. Two wood stoves were installed, one on each floor, using the original chimneys, along with a boiler for wood-pellets with storage in a shed on the property with a culvert into the house. The building has floor heating and natural ventilation. Today one family lives on the first floor and they have a workshop and a pottery on the ground floor.

The measured energy consumption for heat and electricity is $37 \mathrm{MWh} /$ year and the area heated to $10{ }^{\circ} \mathrm{C}$ or more, $A_{\text {temp }}$, is $235 \mathrm{~m}^{2}$. The key figure for energy consumption is $157 \mathrm{kWh} / \mathrm{m}^{2}$ and per year. This is considered low for an old building in this category, type code 826, according to the comparative key figure given, statistic interval $170-208 \mathrm{kWh} / \mathrm{m}^{2}$ and per year, when calculating the energy performance of the building at Boverket's web site [12]. Tyreshill is heated by a boiler for wood-pellets with a storage tank for heated water, and causes no $\mathrm{CO}_{2}$ emissions.

The result of the restoration is a very comfortable house, warm, with no draughts. It has a modern kitchen, bathrooms, space for laundry, and all the facilities needed in a household of today. The two houses' appearance is original but lacks all patina in the interior. Their cultural value is considered moderate but Tyreshill has high value in its context, visibly exposed and located on the hillside as shown in Figure 3 below, and as part of the young community's history. Usability, comfort, and energy issues were prioritized at the expense of the original authenticity and patina, due to its poor original condition. 
Figure 3. Tyreshill's façade, towards Southeast. Photo Eva Gustafsson, Heritage Halland at the Regional Museum Halland.

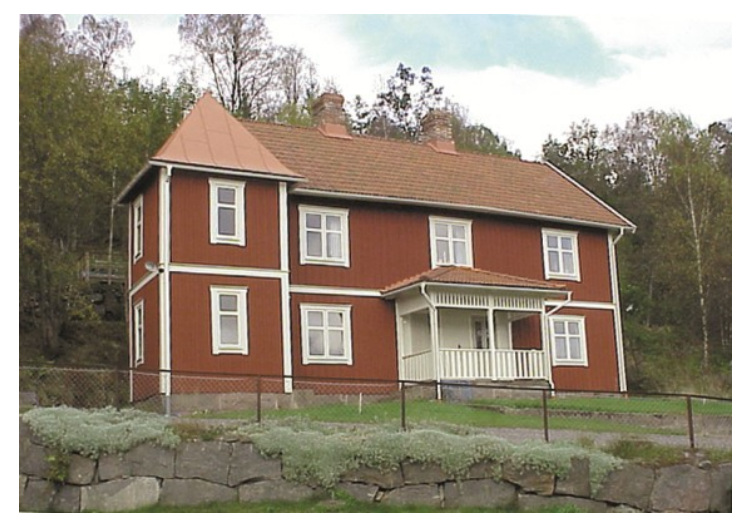

\subsection{Discussion on the Buildings}

The key conclusions are:

(1) All planned maintenance, alteration, and conservation should be based on thorough inventories of the object and its status as well as the users' need for a good indoor environment.

(2) It is possible to make a balanced assessment of the different requirements and make a balanced performance of measures.

In the 1990s the restorations were ambitious about the preservation of values, and this is mirrored in one of the cases studied, Fattighuset in Halmstad, even though it seems that the preservation of cultural value had been given much greater weight than issues of energy efficiency and good indoor climate. A result of that was low usability and difficulties in renting it out. The balanced example with a high level of preservation is Teatern in Laholm where the energy efficiency measures taken were performed with respect for cultural value and the energy use is low in relative terms. In the third case, Tyreshill, a moderate level of preservation of values was obtained considering the poor original state of the building. Its comfort and usability today are great, but the energy use is a bit too high considering the energy efficiency measures carried out.

\subsection{Management and Teamwork}

In Gustafssons's dissertation on the Halland Model an application-oriented theoretical platform and a new model, providing adequate approaches to solve boundary-spanning challenges, is defined. [10].

The keys for the success of the model were:

(1) Horizontal thinking with the choice of a democratic type of management.

(2) Creating involvement by inviting initiatives and discussions.

(3) Small teams to create good working conditions.

(4) A transparent and learning organization.

\subsubsection{How It Was}

The team organization and management has been explored within the Energy Efficiency in Our Cultural Heritage (EEPOCH) research, using interviews with six informants. All informants described 
the Halland Model as a success, which was also the view taken by the media. The Halland Model was created at a time when the national and traditional vertical hierarchy was replaced by a horizontal regional cooperation initiated by the European Commission, EC. Horizontal thinking was permeating the whole concept of the Halland Model and also transferred into the teams at the construction sites.

A major strategy for managing the teams was to choose a democratic type of management and to create inclusiveness. Democratic types are dynamic and transformational, where dynamic leadership is flexible, seizes initiatives, both task oriented and person oriented, and is often process oriented. In the transformational sense it is about setting goals and strategies and conveying these to the co-workers to make them feel involved, engaged, and responsible [13].

A key action was to let everybody on all levels be involved. The overarching objective-save the jobs, save the craftsmanship, save the buildings - could be understood by everybody at the introduction and provided a group identity, even in the orientation phase. The typical second phase of conflict and control was handled by creating a relaxed atmosphere with respect, care, inviting initiatives, and discussions. A high degree of safety was established at the construction sites, the best craftsmen were chosen as supervisors for no more than three apprentices at a time and the teams were small. All measures aimed at creating good working conditions. The organization was transparent and there was also pride and satisfaction in doing something that was appreciated by many, which was further reinforced by the positive image of the Halland Model in the media. Evaluations were made for improvements, which is a sign of a learning organization. The overall assessment is that the informants, the working teams' performance, and the outcome of the restorations were of high quality and both the workers and management are still proud of it.

\subsubsection{How It Could Be}

How can similar management and results be achieved today in preservation when we have completely different conditions within the labor market and in the economy and politics? Earlier management was linear and problem oriented, focusing on products and projects. Contemporary management is using system thinking and focus on processes for optimization, and some are using a systemic approach, recognizing people and complex systems as resources [14].

Using linear assumptions about how different parts in a system work together to solve complicated problems differs from that which is complex. This is an important difference.

When people are involved, a complex process occurs with paradoxes based on time and identity, which is based on human perception, interpretation, and action [15]. In non-linear interactions bifurcations exists within the situation and every situation implies choices, leading to the possibility of multiple futures and surprising responses [16]. In this, there is no ambition to find optimized configurations; rather, there are transformative changes creating new contexts.

People are a complex network of living, creative individuals, reacting and adopting dynamically, and actively trying to create their social environment while being shaped by it. Treating teams and organizations as complex phenomena means taking account of human behavior and the paradoxes created in the interaction between people. Consequently it is also an affirmation of the concrete, actual work performed [15]. 
This is taken into account in a systemic approach and used in systemic meetings; where communication is facilitated through the actors' understanding of each other's actual everyday life, with problems, visions, and ideas [17]. The method can be used in combination with other methods, and could be part of the answer.

\subsection{Laws and Regulations}

The key results are:

(1) Our built heritage is not sufficiently protected by the legislation.

(2) There is a gap to fill concerning the cooperation between the certified energy experts and experts on cultural and historic values.

(3) Contradictory requirements in the legislation make it hard to interpret and to follow, according to the informants.

(4) If restored today, none of the three chosen objects could meet the legislative requirements for energy efficiency and preservation.

Swedish national and official monuments are well protected by their own regulation [18]. The monuments out in the counties also have a protective law, the Heritage Conservation Act, KML [19], which includes buildings, ancient remains and archeological finds, ecclesiastical monuments, and specified artefacts. In Halland there are about 50 protected monuments of 11,000, identified as historically valuable serving as documents of history and cultural layers of development.

The question about what measures could actually be performed in older houses when they are preserved according to the law and mandatory provisions, has a major impact on the results of the research. The plan and building act (PBL) [20] has been amended during the research, as have the mandatory provisions, BBR [7]. The law takes precedence over the mandatory provisions and in the law there is a requirement for caution in relation to cultural, historic and architectural values. There are also general recommendations but they are not mandatory and do not apply to legal context. In Halland the new inventory [3] works as an available list on the Internet, open for anyone to use, but it is not a legal document and in many parts of Sweden there have not been any inventories carried out at all. So what it is possible to do, on a local and regional level, is for the municipal officials in charge to decide.

There is also law SFS 2006:985 [8] and regulation SFS 2006:1595 [9] on energy declarations. All buildings and flats rented out must have an energy declaration, but buildings with cultural, historic, and architectural values are exempt from the requirements. How does an energy expert determine if these values are present in a building? At workshop II, an educator of energy experts confirmed that the education does not contain anything about cultural and historic values. Furthermore, there is education available for becoming a certified expert and inspector of cultural and historic values, as per legislations BFS 2006:6 KUL1 [21] and BFS KUL2 [22], but they do not contain anything about energy efficiency or energy measures and their impact when implemented.

\subsubsection{Results from Interviews}

When interviews were carried out with municipal officials all informants answered similarly. They would rather consider cultural values than make unreasonable demands on energy efficiency, which 
are impossible to fulfill. Usually, they enlist the help of Heritage Halland, a department of the regional museum, and of their conservation officers to assess historic values in individual cases. Sometimes, though, they do not agree and the Building Committee decides on demolition. They all felt that the legal framework is hard to interpret and in the municipalities in Halland there was a desire for clearer and simpler legislation. There are fewer legal documents today than three years ago, but the contradictory requirements for energy efficiency and caution about cultural, historic, and architectural values in the mandatory provisions, BBR, are not easy to follow.

\subsubsection{The Comparison}

For all measures, conservation, new constructions, alteration, etc., there is a requirement for a building permit and it applies for new constructions and existing buildings equally. So also do the mandatory provisions, BBR [7]. The requirement in BBR section 9:2a for housing in the South of Sweden is $90 \mathrm{kWh}$ per $\mathrm{m}^{2} \mathrm{~A}_{\text {temp }}$ and year, and section 9:3a for commercial buildings $80 \mathrm{kWh}$ per $\mathrm{m}^{2}$ $A_{\text {temp }}$ and year, if not heated by electricity, which is shown in Table 2. For buildings heated with electricity the requirements are even more stringent. If the requirements cannot be met for cultural or historic reasons, the requirement can be exceeded by $20 \%$. None of the buildings in this research could manage to meet these requirements if restored today, not even Tyreshill, which was refurbished with added insulation and new windows. There is also another alternative shown in Table 3 below.

Table 2. Measured key figures, $\mathrm{kWh}$ per $\mathrm{m}^{2} \mathrm{~A}_{\text {temp }}$ and year, for the three buildings and interval taken from Boverket's database for existing buildings of the type, age, and use [12].

Requirements for housing and other buildings in BBR section 9:2a and 9:3a are also shown for comparison including the figures exceeded by $20 \%$.

\begin{tabular}{ccccc}
\hline Buildings & $\begin{array}{c}\text { Key figures for } \\
\text { energy use } \\
\text { kWh per } \mathbf{~ m}^{2} \\
\mathbf{A}_{\text {temp }} \text {, year }\end{array}$ & $\begin{array}{c}\text { Boverket's } \\
\text { type code 826 } \\
\text { statistic interval }\end{array}$ & $\begin{array}{c}\text { Energy } \\
\text { requirements BBR } \\
\text { section 9:2a and } \\
\mathbf{9 : 3 a}\end{array}$ & $\begin{array}{c}\text { Requirements } \\
\text { BBR 9:2a and 9:3a } \\
\text { exeeded by 20\% }\end{array}$ \\
\hline Fattighuset & 204 & $144-200$ & 80 & 96 \\
Teatern & 122 & $123-185$ & 80 & 96 \\
Tyreshill & 157 & $170-208$ & 90 & 108 \\
\hline
\end{tabular}

Table 3. If the building after alteration does not meet the requirements in sections $9: 2 \mathrm{a}$ or 9:3a in BBR [7] it should at least have pursued the following U-values, W/ $\mathrm{m}^{2}, \mathrm{~K}$, for the different construction parts. The three buildings in this research are added for comparison.

\begin{tabular}{ccccc}
\hline Construction part & U-values BBR & Fattighuset & Teatern & Tyreshill \\
\hline$U$ roof & 0.13 & $0.15-0.29$ & $0.12-0.14$ & 0.18 \\
$U$ wall & 0.18 & 1.80 & $1.02-1.43$ & 0.29 \\
$U$ floor & 0.15 & $0.26-0.42$ & 0.18 & $0.15-0.42$ \\
$U$ windows & 1.2 & $1.4-4.5$ & $1.9-3.0$ & 2.0 \\
$U$ entrance door & 1.2 & $2.7-4.5$ & $2.29-4.5$ & $2.7-4.5$ \\
\hline
\end{tabular}




\section{Approaches and Methodology Connected to the Methods}

The core idea of the research design is multidisciplinary, and even if an architect should have knowledge and control over many subjects he or she cannot be an expert in all of them. To create the necessary support and guidance a reference group of five people and an expert group of five people are connected to the project. Their professions are conservators and antiquarians of built heritage, energy and construction engineers and architects. Some represent the academy and some work out in practice. Local companies and organizations are also participating: four municipally owned real estate companies and one municipality, three energy and utility companies, and two minor companies in energy counseling and in vocational education, and finally the Region Halland and the Heritage Halland. Six workshops were carried out where in total 95 people attended, see Table 4 below. All participating professionals, academics, and practitioners could meet for lectures and discussions on the case, and on the results of the research project and its further direction.

Table 4. The participating professionals in the six workshops.

\begin{tabular}{ccccccc}
\hline Participants & WS I & WS II & WS III & WS IV & WS V & WS VI \\
\hline Antiquarians & 5 & 1 & 10 & 2 & 5 & 4 \\
Engineers & 10 & 11 & - & 5 & 3 & 4 \\
Architects & 3 & 3 & 6 & 7 & 12 & 4 \\
Total & 18 & 15 & 16 & 14 & 20 & 12 \\
\hline
\end{tabular}

The participating professionals have also been consulted for advice and/or corroboration and support in parts of the multiple case study. Architectural and use values, and laws and regulations became new embedded units of analysis due to the workshops, which have come to direct the research. Making use of knowledge and skills in other academic disciplines is interdisciplinary and connecting academy and practice is transdisciplinary, and the added approaches have rooted the research in approved practice and theory.

\section{The Multiple Case Study as a Methodology}

Case studies can be used for exploratory, explanatory, and descriptive research, as stated by Robert K. Yin [23], and hence a framework of a multiple case study was an appropriate choice. The methodology provides a firm yet permissive structure for a mix of methods, approaches, and embedded multiple units of analysis, according to Yin's definitions [23]. According to Yin [23] there are three principles of data collection to construct validity and reliability of the case study and for convergence of evidence. These are to use multiple sources, to create a case study database, and to maintain a chain of evidence, and these principles have been followed in this study. The theoretical model for balancing requirements will emerge from the cases, some of which show similar predicted results, a literal replication, while some show predicted contrasting results for anticipatable reasons, a theoretical replication. In brief it is about using pattern matching and analytical means to generalize a set of results to explore a possible hypothesis or broader theory. Triangulation has been performed when investigating the buildings' energy performance, and in the assessment of cultural and historic values. Assessment of architectural values in situ has been performed by one architect, using archive 
information and an approved guide for assessment, and own and other practitioners' experiences, knowledge, and skills. Management and teamwork, and the impact of the legislative framework, have been illuminated by using interviews.

\section{The Methods and the Units of Analysis}

The units of analysis are listed in the Table 5 below.

Table 5. Main aspects investigated in this study and the methods and basis for the survey that were used for each unit of analysis.

\begin{tabular}{lll}
\hline Units of analysis & $\begin{array}{l}\text { Main aspects to explore, describe } \\
\text { and analyse }\end{array}$ & Methods and base for survey \\
\hline Energy efficiency & measures & archive studies and search \\
& approaches & measures in situ \\
& accomplishments & calculation of energy balances \\
& results & literature studies \\
Cultural and historic values & estimates and assessments & workshops I-V \\
& approaches & archive studies and search \\
& accomplishments & assessments in situ \\
& results & literature studies \\
Architectural values and & estimates and assessments & workshops I-V \\
use value & approaches & archive studies and search \\
& accomplishments & assessments in situ \\
results & literature studies \\
Management, teamwork & strategies, methods and processes & workshops I-V \\
& approaches & archive studies and search \\
& accomplishments & literature studies \\
& results & interviews \\
& content and meaning & workshops V-VI \\
& impact of implementation & literature studies \\
& approaches & interviews \\
& & workshops I-IV \\
\hline
\end{tabular}

All five units of analysis have been applied to the objects and the conservation work carried out. The three buildings where chosen after screening all of the restored objects and environments within the Halland Model. The aim was to find examples where the energy measures and preserved historic values had been balanced.

\subsection{Methods Used for Exploring Energy Efficiency}

The processes of making assessments of values and energy balances are complicated because the situation consists of a vast number of interacting elements, which makes the work and calculations difficult to perform, although all elements and interactions might be known. A complicated process though, may be divided and reduced to solvable parts for creating optimized solutions. Based on linear assumptions on how the parts work together, complicated problems can be solved. 
The evaluation of energy performance started with archive studies to find out the buildings' constructions and then the assessment was carried out in three ways: with IR camera in situ, by manual calculations of their energy balances, and by measuring actual energy consumption. Differences in these figures can show good maintenance but could also detect problems indicating actions to be taken and showing what can be improved. When preparing the protocol for the manual calculations, eight different books and guides were used [24-31]. A traditional $\lambda$-value calculation was chosen for the transmission losses through the envelopes and three engineers were also consulted for guidance, discussion and improvements on the chosen method. Heat loss through ventilation was calculated with a simplified rule of thumb-method learned from, and used by, practitioners and is a sufficient method for an architect to use. All methods are reported in Norrström's licentiate thesis [32]. No calculation model is without flaws, but the strength is in using the exact same procedure in every object for an accurate comparison between them, ensuring the reliability of the case study.

The buildings' energy performance, how to assess it, and the different associated measures and risks, such as mold growth, were discussed in workshops I to IV. In both workshops I and IV, risks for mold growth, added insulation, and new materials were discussed. The buildings' properties, values and measures and how different professions experience them were discussed in workshop V.

Comments on Calculated and Measured Energy Demand

When comparing the calculated key figures with the measured ones, some assumptions can be made. The figures are shown in Table 6 below.

Table 6. Comparison of measured and calculated key figures for the buildings.

\begin{tabular}{ccc}
\hline Buildings & $\begin{array}{c}\text { Measured key figures for energy } \\
\text { use } \mathbf{k W h} \text { per } \mathbf{m}_{\mathbf{2}} \mathbf{A}_{\text {temp }} \text { year }\end{array}$ & $\begin{array}{c}\text { Calculated key figures for energy } \\
\text { use } \mathbf{k W h} \text { per } \mathbf{~ m}_{\mathbf{2}} \mathbf{A}_{\text {temp }}\end{array}$ \\
\hline Fattighuset & 204 & 191 \\
Teatern & 122 & 146 \\
Tyrehill & 157 & 174 \\
\hline
\end{tabular}

The difference between Fattighuset's calculated and measured figures depend mainly on air leakage through the openings in the envelope: windows and door which are not airtight, and the air vents causing a cold draught which has to be countered by increased heat supply. This was not taken into account in the calculations. Furthermore, the photos taken with an IR camera, together with the calculations on moisture and condensation in the construction, indicate that there are risks for condensation and mold growth at thermal bridges.

The low measured figures in Teatern, compared with the calculated ones, are due to the ventilation system with supply air and exhaust air, with heat recovery, in combination with the flexible and energy efficient installations adjustable to the activities and the use of the premises. The efficiency and automatic adjustability of the system was not foreseen and not included in the calculations. The automatic and adjustable control and regulation system in Tyreshill is the most plausible explanation for the divergent figures on measured and calculated energy use. When the two woodstoves are in use the automatic temperature regulation decreases the supply of heat from the main distribution system, and the extra heat from the woodstoves is not included in the calculation. 


\subsection{Methods Used for Exploring Cultural and Historic Values}

Data for analysis of preserved historic values were collected from archive files at Heritage Halland and the municipality archives. Reports, drawings, documents and photos were analysed as well as information from the evaluation of the physical artefacts in situ. Information from people engaged in the conservation work was also documented and analysed. The Swedish National Heritage Board's handbook [33] was used for assessment in situ. Basic and enhanced motives for preservation and the other subcategorized values were defined and processed with the reinforced and overall motives. The inventory in situ was registered by the investigator, and a conservation officer individually on different occasions and the data was used for a comparison with earlier inventories for a thorough triangulation. This was also an appropriate way to enhance the construct validity by using multiple sources of evidence, according to Yin [23].

Cultural and historic values were also discussed in workshops I to IV in relation to the energy issue, and possible measures for energy efficiency. Workshop III had risks and opportunities in the heritage sector and new strategies as a special theme, and the National Heritage Board demonstrated a new model for assessing historic values at this workshop. The theme for workshop V was the buildings' properties, values, and measures and how different professions experience them.

\subsection{Methods Used for Exploring Architectural Values and Use Values}

Information on how to assess the architectural values was expected to be found in the National Heritage Board's handbook, but the content was not sufficient from an architect's point of view. There is no Swedish handbook, or guide, on how to make an overall assessment of architectonic qualities or values. The solution, determined after consulting a professor in the theory of architectural history, was to use CABE's, the Commission for Architecture and the Built Environment's, Design Review [34], which is a tried and tested method of promoting good design.

Usually there are a number of different design approaches, which work in response to a given set of circumstances when designing for a new site. All these approaches can be of use when analysing an existing building and its context. This study concerns existing buildings but the Design Review also applies in these cases. Architectural qualities are signs of value as well as physical properties, and when they are considered to be good they are desirable both in planned and in existing buildings. Only the most basic and common aspects were addressed in this study. With archive studies and photos of the buildings as a base, assessments were performed in situ using the CABE Design Review as a guide. The guidance delineated by CABE was used to avoid a subjective selection of aspects.

\subsection{Methods Used for Exploring Management and Teamwork}

In Gustafsson's dissertation on the Halland Model, a generic and entrepreneurial concept or model is developed where the 'trading zone' is defined as an active arena for negotiations and exchange of services or a field of force corresponding to the actor's policies, values and resources. Further on, he describes the Model theoretically as a network with a collaborative approach, and the research as action research with an inside agent (Gustafsson) being involved in the whole process of the Halland Model [10]. In EEPOCH the perspective is from the outside, in opposition to Gustafsson's inside perspective. 
Interviewing people engaged in the restorations was an explorative process. The first method used for understanding of the management and teamwork was rereading about leadership and management from three known written sources; Larsson, Maltén, and Larsen [14,35,36]. Secondly, the archive material concerning management was studied, and thirdly, a guide was used for learning more about interviewing. An anthropologist was consulted for advice on how to carry out interviews and Russel Bernard's guide [37] was recommended and used. The interviews and conversations with involved professions were performed, and finally the partly transcribed recordings were compared and analyzed to obtain coherent results. This was a time consuming task and three conservation officers, two engineers and one architect were engaged for open-ended interviews.

Workshop $\mathrm{V}$ had properties and values as a theme for discussion to find out how the different professions - antiquarians of built heritage, engineers, and architects - experience them, how they make assessments and how they evaluate data. The aim is to compare methods to find similarities rather than differences, and to learn and create understanding of each other's work and profession. The last workshop, VI, focused on cooperation between the different professions involved in the heritage sector, a systemic approach was explored, and a systemic meeting was tested with help from an experienced professor emeritus specialising on the subject.

\subsection{Methods Used for Exploring Laws and Regulations}

The methods for understanding the legislative framework were mainly reading and analyzing, but to know how the requirements for energy use and caution were implemented out in the municipalities, contact with municipality officials, who work with planning and handling building permits, was necessary. The aim was to find out how municipal officials interpret and use the laws, regulations, and mandatory provisions. Proper but simple and semi-structured interviews were carried out in the tradition of social science, using Bernard's guide for support [37]. One civil servant and five municipal officials were addressed. The mandatory regulations were also theoretically implemented in the three chosen buildings and a comparison was made including the comparison of other existing buildings of the same type, age, function, and use, details of which are available in Boverket's database on their website [12].

The laws and regulations, and their impact when implemented, were discussed from the first workshop and had to become a unit of analysis, which was not planned from the beginning. The issue of law and regulation was discussed when it was revealed that a new major refurbishment was planned for Fattighuset, and it has arisen regularly in almost every discussion and workshop. The outcome of the workshops has been directing the research in this way.

\section{Conclusions}

The overall conclusions drawn from the results so far, and in short, are:

(1) There is a risk of losing historic and architectural values due to energy measures being carried out.

(2) There is a risk that potential for energy efficiency measures will not be realized due to overcautious management. 
(3) It is possible to make a balanced assessment of the different requirements, and make a balanced performance of measures.

(4) A new strategic agenda is needed for sustainable development of the heritage sector with renewed focus on proactive work.

(5) There is a lack of inventories of cultural and historic values in the existing building stock.

(6) Coordination and cooperation between experts on energy efficiency and inspectors of cultural values would facilitate their work.

(7) A general guide for architectural and use values, for use on a municipal level, would facilitate the work of local boards of building and planning.

(8) A requirement for antiquarian investigation to determine a building's values for protection could be added to the level of mandatory provisions.

The two risks, stated in the introduction, emanating from climate change and our efforts to cope with and mitigate its effects, have been illuminated in this paper. There is a risk that the new focus on energy efficiency for cutting the net emissions of greenhouse gases manifest in the new legislation will cause loss of cultural, historical, and architectural values. This was a fact in Tyreshill, which was totally refurbished, but in this case the added insulation did not cause any problems with mold growth. Looking at the buildings one can see that there are conflicting interests in the supply of heat: low supply of heat to lower the energy use and costs becomes too low to handle humidity and moisture problems causing damage to the construction. This happened in Fattighuset, although the façades were not insulated there. A structure, which is not dry, always has a higher energy demand for keeping the indoor temperature at a desired level. A good precautionary measure is to always make risk calculations for moisture and mold growth in all inventories before deciding on any measures or actions. One comment on Fattighuset must be that air tightness and control of air humidity and temperatures are also crucial for avoiding discomfort in existing buildings. Furthermore, installation of mechanical ventilation or air handling systems alters the interior historic values of a building, as in Fattighuset, if it is not performed with sensitivity, as in Teatern.

There is also a risk that actual energy efficiency potentials are not being realized because of too much caution. Looking at Fattighuset with its great preserved details, authenticity, and patina, and measuring the indoor climate, it is evident that the conservation work has been performed at the expense of energy efficiency and, moreover, at the expense of a good and healthy indoor climate. The difficulties with interpreting the requirement for caution and defining it clearly in law, regulation, and mandatory provisions, are potential risks. The balance of different requirements in assessing applications for building permits can tip to favour either the energy requirement or the preservation requirement. The balanced example is Teatern, and the work performed there can serve as a guide.

An overall conclusion is that a more coherent and balanced strategic agenda is needed for sustainable development of the heritage sector, for smaller communities as well as at the national level, to meet the challenges originating from the climate change issue. Sustainability is at the core of the work within the heritage sector where long term management includes local or regional and natural, hence durable materials, using local or regional craftsmen, recycling, and use of renewables. The traditional protective work within the heritage sector has, through integrated conservation, been transformed into proactive work and must now focus even more on the proactive. 
The National Heritage Board's handbook and guide for assessing historic values and for management of the restoration process could be updated or a complementary guide could be produced. They have already initiated a project for this and tested one new method for assessing values. This was presented at workshop III by the National Heritage Board, and the outcome will be expected in the near future.

Thorough inventories of our cultural, historic, and architectural values in the national existing building stocks would make it easier for municipality officials, administrating building permits, to determine when the requirement for caution applies. The lack of a guiding inventory of the existing buildings and cultural environments also complicates much of the daily work within the heritage sector. It would in many cases be easier and more practical to have a documented inventory to use and to refer to.

Our built cultural heritage is exempt from the requirement for energy declarations, but how can the energy experts determine which buildings and what values to look for? An inventory would facilitate their work too. Furthermore, there could be coordination between the certifying courses for energy experts and those for experts in, and inspectors of, cultural and historic values, as well as more cooperation in general to make them aware of one another's work.

The lack of a general guide for architectural values and use values of the kind found e.g., in the United Kingdom, with CABE's guiding principles [34], makes it difficult to maintain these values in the construction process when an alteration in an existing building is carried out. It would be practical to have a document to refer to at a municipality level where the decisions are made by the local board of building and planning, which consists of politicians who are laymen in the field.

Some of the laws and regulations pertaining to heritage and existing constructions are perceived as inadequate according to the municipal officials interviewed in Sweden. There is an incommensurability mirrored in the new BBR, the mandatory provisions [7], concerning how to balance the required energy efficiency with the requirement for caution in historic buildings, and the law PBL [20] is not sufficiently detailed to be used on the level of handling building permits. The mandatory provisions, BBR, could be enhanced with a requirement for antiquarian investigation to determine all buildings' values for protection if they are 60 years old or older, as Alois Riegl once suggested [38]. Lifting the general recommendations in BBR [7] to the level of mandatory provisions, where possible, would also reduce the risk of arbitrary judgments and interpretations of the requirement for energy efficiency as well as for the requirement for caution with historic values.

These are the main suggestions or recommendations at a national level, arrived at through this research project. If a similar situation for the heritage sector exists in other geographical areas, which is not impossible, the parts and the whole of this research can be transferred and be of use for continued sustainable development within the wider heritage sector.

\section{Acknowledgments}

The author is grateful to antiquarians of the built environment Maja Lindman and Britt-Marie Lennartsson for help with triangulation in the assessment of cultural and historic values, and to the engineers for all good advice on energy calculations, the expert group and the reference group, and all participants at the workshops for contributing with their knowledge and great experience. 
This research, Energy Efficiency in Our Cultural Heritage, EEPOCH, is one of the projects within the Save and Preserve program financed by the Swedish Energy Agency and in this particular case also by regional and local organizations and companies in the county of Halland, Sweden.

\section{Conflict of Interest}

The author declares no conflict of interest.

\section{References and Notes}

1. United Nations Educational, Scientific and Cultural Organisation. Convention Concerning the Protection of the World Cultural and Natural Heritage; UNESCO: Paris, France, 1972.

2. Calvino, I. Invisible Cities; Harcourt Inc.: Orlando, FL, USA, 1974; p. 10.

3. Bebyggelseinventeringen Halland. Available online: http:/geoservices.lst.se/bebyggelseinventering/ (accessed on 25 March 2013).

4. Directive 2009/28/EC of the European Parliament and of the Council on the Promotion of the use of energy from renewable sources. Available online: http:/eur-lex.europa.eu/LexUriServ/ LexUriServ.do?uri=Oj:L:2009:140:0016:0062:en:PDF (accessed on 25 March 2013).

5. Directive 2012/27/EU of the European Parliament and of the Council on energy efficiency. Available online: http://eur-lex.europa.eu/JOHtml.do?uri=OJ:L:2012:315:SOM:EN:HTML (accessed on 25 March 2013).

6. Directive 2010/31/EC of the European Parliament and of the Council on the energy performance of buildings. Available online: http://eur-lex.europa.eu/LexUriServ/LexUriServ.do?uri= OJ:L:2010:153:0013:0035:EN:PDF (accessed on 25 March 2013).

7. Boverkets byggregler. Available online: http://www.boverket.se/Global/Webbokhandel/ Dokument/2011/BFS-2011-6-BBR-18.pdf (accessed on 25 March 2013).

8. SFS 2006:985, Lag om energideklaration för byggnader. Available online: http://www.riksdagen.se/sv/Dokument-Lagar/Lagar/Svenskforfattningssamling/Lag-2006985-omenergideklar_sfs-2006-985/ (accessed on 25 March 2013).

9. SFS 2006:1592, Förordning om energideklaration av byggnader. Available online: http://www.riksdagen.se/sv/Dokument-Lagar/Lagar/Svenskforfattningssamling/Forordning-20061592om-ener_sfs-2006-1592/(accessed on 25 March 2013).

10. Gustafsson, C. The halland model: A trading zone for building conservation with labour market policy and the construction industry, aiming at regional sustainable development. Ph.D. Thesis, Chalmers University of Technology, Göteborg, Sweden, 2009.

11. Naturvårdverket. Emission factors. Available online: http://www.naturvardsverket.se/sv/Start/ Klimat/Utslappsminskning/Berakna-utslapp/Emissionsfaktorerkoldioxid/ (accessed on 25 March 2013.)

12. Boverket. Energideklarationsberäkning. Available online: http://gripenberakning.boverket.se/ GripenPublic/Forms/Default.aspx (accessed on 25 March 2013).

13. Larsson, G. Ledarskapsteori. In Direkt Ledarskap, 2nd ed.; Larsson, G., Kallenberg, K., Eds.; Försvarsmakten: Stockholm, Sweden, 2006; pp. 30-55.

14. Larsson, G., Kallenberg, K., Eds. Direkt Ledarskap, 2nd ed.; Försvarsmakten: Stockholm, Sweden, 2006. 
15. Nilsson, F. Att möta framtidens utmaningar på rätt sätt (in Swedish). In Tänk om, 1st ed; Ainalem, I., Lindström, B., Garsén, J., Eds.; Studentlitteratur AB: Lund, Sweden, 2013; pp. 93-110.

16. Allen, P.M. Knowledge, ignorance and learning. Emergence 2000, 4, 78-103.

17. Sarv, H. Systemiska möten. In Tänk om, 1st ed.; Ainalem, I., Lindström, B., Garsén, J., Eds.; Studentlitteratur AB: Lund, Sweden, 2013; pp. 113-128.

18. Förordning om Statliga Byggnadsminnen (in Swedish); SFS 1988:1229; Riksantikvarieämbetet: Stockholm, Sweden, 1988.

19. Heritage Conservation Act (in Swedish); SFS 1988:950; Riksantikvarieämbetet: Stockholm, Sweden, 1988.

20. Plan-och Bygglagen (in Swedish); SFS 2010:900, PBL; Riksdagen: Stockholm, Sweden, 2010.

21. Boverket. Sakkunniga Kontrollanter av Kulturvärden (in swedish); BFS 2006:6. KUL1; Boverket: Karlskrona, Sweden, 2006.

22. Boverket. Sakkunniga Kontrollanter av Kulturvärden (in swedish); BFS 2011:15. KUL2; Boverket: Karlskrona, Sweden, 2011.

23. Yin, R.K. Case Study Research: Design and Methods, 4th ed.; Sage Publications Inc.: Thousand Oaks, CA, USA, 2009.

24. Abel, E.; Elmroth, A. Byggnaden Som System (in Swedish), 2nd ed.; Forskningsrådet Formas: Stockholm, Sweden, 2008.

25. Adalbert, K.; Wahlström, Å. Energibesiktning av Byggnader-Flerbostadshus och Lokaler (in Swedish); SIS Förlag: Stockholm, Sweden, 2008.

26. Adamson, B.; Hidemark, B. Sol-energi-form Utformning av Lågenergihus (in Swedish); Byggforskningsrådet: Stockholm, Sweden, 1986.

27. Anderlind, G.; Stadler, C.-G. Isolerguiden Bygg 06; Swedisol: Väring, Sweden, 2006.

28. Boverket. Energihushållning Enligt Boverkets Byggregler 2009. Available online: http://www.boverket.se/Global/Webbokhandel/Dokument/2009/Energihushallning_enligt_Boverkets_ byggregler.pdf (accessed on 25 March 2013).

29. Elmroth, A. Energihushållning och Värmeisolering, Byggvägledning 8 (in Swedish); Svensk Byggtjänst: Stockholm, Sweden, 2009.

30. Petersson, B.-Å. Byggnaders klimatskärm: Fuktsäkerhet Energieffektivitet Beständighet (in Swedish); Studentlitteratur AB: Lund, Sweden, 2009.

31. Wärme, P. Energisparboken: Halvera Elräkningen-men Behåll din Standard (in Swedish); Teknografiska Institutet: Solna, Sweden, 1991.

32. Norrström, H. Energy Efficiency and Preservation in Our Cultural Heritage: EEPOCH. Licentiate thesis, Chalmers University of Technology, Göteborg, Sweden, 2011.

33. Unnerbäck, A. Kulturhistorisk Värdering av Bebyggelse (in Swedish); Riksantikvarieämbetet: Stockholm, Sweden, 2002.

34. CABE. Design Review: How CABE Evaluates Quality in Architecture and Urban Design; CABE-Commission for Architecture and the Built Environment: London, UK, 2006.

35. Maltén, A. Kommunikation och Konflikthantering, en Introduktion (in Swedish); Studentlitteratur AB: Lund, Sweden, 1998.

36. Larsen, R.-P. Teamutveckling; Studentlitteratur AB: Lund, Sweden, 2003. 
37. Bernard, R. Research Methods in Anthropology: Qualitative and Quantitative Approaches, 4th ed.; Alta Mira Press: Oxford, UK, 2006.

38. Arrhenius, T. The Fragile Monument: On Conservation and Modernity; Artifice Books on architecture: London, UK, 2012; p. 96.

(C) 2013 by the authors; licensee MDPI, Basel, Switzerland. This article is an open access article distributed under the terms and conditions of the Creative Commons Attribution license (http://creativecommons.org/licenses/by/3.0/). 